\title{
Solid waste management in India: a review
}

\author{
Saumya $\operatorname{Singh}^{1} *$, Jeeoot $\operatorname{Singh}^{2}$ \\ ${ }^{1 *}$ Mechanical Engineering Department, Indian Institute of Technology, Dhanbad, INDIA \\ ${ }^{2}$ Mechanical Engineering Department, Madan Mohan Malaviya University of Technology, Gorakhpur, INDIA \\ "Corresponding Author: e-mail: saumyasingh.1195@gmail.com
}

\begin{abstract}
In India, rate of waste generation varies from $0.12-0.60 \mathrm{~kg} / \mathrm{capita} / \mathrm{day}$. This paper lists established solid waste management practices in India by providing the latest factual data from various reports and surveys being conducted in India in the period 2016 and beyond. This paper also gives an insight into some of the recent studies that have been in India related to solid waste and waste to energy technologies by describing their study area along with mentioning their critical observations.
\end{abstract}

Keywords: Solid waste management, waste to energy, incineration, refuse derived fuel (RDF), gasification, anaerobic digestion, landfill.

DOI: http://dx.doi.org/10.4314/ijest.v13i1.8S

Cite this article as:

Singh S., Singh J. 2021. Solid waste management in India: A review, International Journal of Engineering, Science and Technology, Vol. 13, No. 1, pp. 54-60. doi: 10.4314/ijest.v13i1.8S

Received: December 1, 2019; Accepted: February 5, 2021; Final acceptance in revised form: March 31, 2021

This paper was earlier presented at the International Conference on Energy, Environment \& Material Sciences (ICE2M), 1-3 December 2019 and substantially improved for this Special Issue. Guest Editor: Dr. Sri Niwas Singh, Professor (HAG), Department of Electrical Engineering, Indian Institute of Technology Kanpur, 208016 (U.P.) India, former Vice-Chancellor, Madan Mohan Malviya University of Technology Gorakhpur (April 2017 to July 2020).

\section{Introduction}

The municipal wastes budgets in high income countries account for about $4 \%, 10 \%$ for middle income countries and $20 \%$ for low income countries. The waste induced/person/day ranges from 0.11-4.54 kilograms or an average of 0.74 kilograms, accounting to total 2.01 billion tonnes annually worldwide in 2016. The statistics is expected to increase by 2050 , to 3.40 billion tonnes. The projected increase of daily waste generation in high-income countries is $19 \%, 40 \%$ for middle-income and low-income countries, as per the World Bank's report in 2018 (Kaza et al, 2018). The waste generation and its projection in India as per the world bank report is based on per capita waste generation daily rates published by the CPHEEO, segmented by population groups.is illustrated in the table 1. Population was taken from 2011 census. Calculations as follows: Population $>5$ million, $0.5 \mathrm{~kg} / \mathrm{person} / \mathrm{day}$; Population between 2-5 million, $0.35 \mathrm{~kg} / \mathrm{person} / \mathrm{day}$ (Kaza et al, 2018, pp 199).

Table 1. Waste generation and its projection in India as per World Bank report (Kaza et al, 2018)

\begin{tabular}{|c|c|c|c|}
\hline \multirow{2}{*}{ Country } & Year & Population ('000s) & MSW Generation \\
\hline \multirow{2}{*}{$\begin{array}{c}\text { Income: Low- Middle } \\
\text { Income Country }\end{array}$} & 2001 (origin year reported) & $1,071,477$ & $168,403,240$ \\
\cline { 2 - 4 } & 2016 adjusted & $1,324,171$ & $277,136,133$ \\
\cline { 2 - 4 } & 2030 projected & $1,512,985$ & $387,770,524$ \\
\cline { 2 - 4 } & 2050 projected & $1,658,978$ & $543,277,457$ \\
\hline
\end{tabular}


According to the NEERI project sponsored by CPCB for 24 state capitals and 35 metro cities in India, rate of waste generation varied from 0.12-0.60 kg/capita/day. The observed carbon nitrogen $(\mathrm{C} / \mathrm{N})$ ratio was $20-40 \%$ and the moisture content ranged from $30-60 \%$ (NEERI, 2005). Waste to energy realises the waste potential which is sustainable source of energy as well as reduces harmful effects on environment, exclusively for developing countries (Kumar et al, 2017).

If 1 tonne municipal solid waste is incinerated rather than landfilled for same amount of electricity generation as by power plants based on fossil fuel, then avoided equivalent emissions of carbon dioxide amount to 1.3 tonnes (Kumar et al, 2017 and ASME, 2008). Also, if 1 million tonne waste is processed per pear in a waste to energy plant having average 30 years working life will require land area less than $100,000 \mathrm{~m}^{2}$, whereas, if 30 million tonne waste is landfilled, it will require land of about $300,000 \mathrm{~m}^{2}$ (Kumar et al, 2017). This paper lists the established setup, operational plants and the planned setups.

\section{Waste to Energy Options}

Waste composition and its characteristics are necessary parameters to determine the energy production rate. Particle size, content of moisture, density and its calorific value influences the selection of waste to energy strategy (CPCB, 2016). For faster rate decomposition organic waste size of particle should be less, high density instead of low density (such as plastics, paper, cardboard). In case of anaerobic digestion suitability increases with high moisture content (Beyene et al, 2018). In India, organic material in waste is high upto $40-60 \%$, inert content is also high (30-50\%) along with high moisture content (40-60\%) and low calorific value of about 800-1100 kcal/kg (Kaushal et al, 2012). Table 2 shows cumulative deployment of various renewable energy systems and devices as on 31st December, 2016 in the annually issued MNRE report 2016-17 where progress of biopower has been revised to installed capacity from exportable power capacity (MNRE, 2017). The cumulative power generating projects using biomass of capacity 7907.34 MW have been commissioned successfully. Power capacity from off-grid biomass gasifiers in industries including 8 rice mills, some flour mills, bakeries for fulfilling captive demand of thermal and electricity applications were installed during 2016-17 in several states (MNRE, 2017).

Table 2. Cumulative deployment of various renewable energy systems and devices as on $31^{\text {st }}$ December, 2016 (MNRE, 2017)

\begin{tabular}{|c|c|c|}
\hline Sector & Achievement during 2016-17 & Cumulative achievements \\
\hline \multicolumn{3}{|c|}{ I. Grid-Interactive Power (Capacities in MW) } \\
\hline Bio Power (Biomass \& Gasification and Bagasse Cogeneration) & 151.40 & 7907.34 \\
\hline Waste to Power & 7.50 & 114.08 \\
\hline \multicolumn{3}{|c|}{ II. Off-Grid/ Captive Power (Capacities in MWEQ) } \\
\hline Waste to energy & 4.47 & 163.35 \\
\hline Biomass(non-bagasse) Cogeneration & 0.00 & 651.91 \\
\hline \multirow[t]{2}{*}{ Biomass Gasifiers } & Rural-0.00 & Rural-18.34 \\
\hline & Industrial-4.30 & Industrial-168.54 \\
\hline \multicolumn{3}{|c|}{ III. Other renewable energy systems } \\
\hline Family Biogas Plants (in Lakhs) & 0.35 & 49.40 \\
\hline
\end{tabular}

2.1 Thermal conversion: Dry waste with less moisture content and more percentage of organic matter of non-biodegradable kind is used for thermal conversion to produce fuel oil, heat energy or gas. The treatment rate of the total collected waste is only $19 \%$, and the available WTE treatment facilities in India are: 8 WTE plants, 29 RDF facilities, 172 bio-methanation facilities, 138 vermicomposting and 279 conventional composting facilities (Mohapatra, 2015).

2.2 Incineration: According to the IEA, the minimum calorific value for operating incineration to be feasible should be 1900 $\mathrm{kcal} / \mathrm{kg}$. municipal solid waste in India mainly consists of 40-60\% organic matter and 30-50\% inert content with calorific value as low as 800-1100 kcal/kg and moisture content as high as 40-60\% (Kaushal et al, 2012). Also, the costs for setting up as well as running the incineration plants are very high. In 1987, at Timarpur, New Delhi first municipal solid waste incineration large scale plant with 300 tonnes/day capacity 250 million Indian rupees was constructed but it went un-operational after six months due to its unsatisfactory performance. However, small incinerators for burning hospital wastes were still used (CPCB, 2016). Table 3 shows massive power output incineration plants initiatives in India (Mohapatra, 2015 and CPHEEO, 2014).

Table 3. Massive power output incineration plants initiatives in India (Mohapatra, 2015 and CPHEEO, 2014)

\begin{tabular}{|l|c|c|c|c|c|c|}
\hline \multicolumn{1}{c}{$\begin{array}{c}\text { Plant name, } \\
\text { City }\end{array}$} & Initiative & $\begin{array}{c}\text { Utilisation Waste } \\
\text { Capacity } \\
\text { (tonnes/ day) }\end{array}$ & $\begin{array}{c}\text { Estimated/ Running } \\
\text { Power Output } \\
\text { (MW) }\end{array}$ & $\begin{array}{c}\text { Starting } \\
\text { year }\end{array}$ & $\begin{array}{c}\text { Closing } \\
\text { year }\end{array}$ & $\begin{array}{c}\text { Refuse derived } \\
\text { fuel production } \\
\text { (tonnes/day) }\end{array}$ \\
\hline $\begin{array}{l}\text { Timarpur, } \\
\text { Delhi }\end{array}$ & - & 350 & 3.75 & 1986 & 1991 & - \\
\hline $\begin{array}{l}\text { Gol, Mumbai } \\
\text { Gandamguda, } \\
\text { Hyderabad }\end{array}$ & Selco International Ltd & 250 & - & 1994 & Abandoned \\
\hline
\end{tabular}


Table 3 (cont'd). Massive power output incineration plants initiatives in India (Mohapatra, 2015 and CPHEEO, 2014)

\begin{tabular}{|c|c|c|c|c|c|c|}
\hline $\begin{array}{l}\text { Plant name, } \\
\text { City }\end{array}$ & Initiative & $\begin{array}{c}\text { Utilisation Waste } \\
\text { Capacity } \\
\text { (tonnes/day) }\end{array}$ & $\begin{array}{l}\text { Estimated/ Running } \\
\text { Power Output } \\
\text { (MW) }\end{array}$ & $\begin{array}{l}\text { Starting } \\
\text { year }\end{array}$ & $\begin{array}{l}\text { Closing } \\
\text { year }\end{array}$ & $\begin{array}{l}\text { Refuse derived } \\
\text { fuel production } \\
\text { (tonnes/day) }\end{array}$ \\
\hline Vijaywada & Shriram Energy & 650 & 6 & 2003 & 2009 & - \\
\hline Lucknow & $\begin{array}{l}\text { Asia Bio- energy India Ltd and } \\
\text { Enkem Engrs Pvt Ltd }\end{array}$ & 600 & 5 & 2003 & 2003 & - \\
\hline $\begin{array}{l}\text { Timarpur- } \\
\text { Okhla, Delhi }\end{array}$ & Jindal ITF Ecopolis & 2000 & 16 & \multicolumn{2}{|c|}{ Operational since 2011} & 450 \\
\hline $\begin{array}{l}\text { Ghazipur, } \\
\text { Delhi }\end{array}$ & ILFS & 1,300 & 10 & \multicolumn{2}{|c|}{ Operational since 2016} & 433 \\
\hline Bangalore & $\begin{array}{c}\text { Srinivasa Gayithri Resources } \\
\text { Recovery Ltd and Bruhat Bangalore } \\
\text { Mahanagar Palike (BBMP) }\end{array}$ & - & 8 & \multicolumn{2}{|c|}{ Abandoned } & - \\
\hline Pune & Rochem Green Energy Pvt Ltd & 650 & 10 & \multicolumn{2}{|c|}{ Operational since 2012} & - \\
\hline $\begin{array}{l}\text { Nalagonda, } \\
\text { Hyderabad }\end{array}$ & - & 800 & 11 & \multicolumn{2}{|c|}{ Yet to commission } & - \\
\hline Kanpur & $\mathrm{A} 2 \mathrm{Z}$ & 700 & 12 & \multicolumn{2}{|c|}{ Yet to commission } & - \\
\hline Narela, Delhi & Ramky & 1400 & 24 & \multicolumn{2}{|c|}{ Yet to commission } & - \\
\hline
\end{tabular}

In Vijaywada plant the proposal was to convert solid waste into RDF pellets for loading onto the boiler to be burnt along with other fuels and generate power capacity of $6 \mathrm{MW}$ per day. Due to no sustainability and high operational costs the plant was shut down after 2009 (Mohapatra, 2015). The important features of waste to energy plant in Ghazipur are that pre-processing is done, dryers and shredders of high quality are present, it is not dependent on biomass or some other supplementary fuel. One of its salient features is that its design conforms to EURO norms by inhibiting high standard measures to control pollution like treatment of flue gas, dust, odour and noise control (Mohapatra, 2015).

Table 4. Statistics related to bio-energy potential, solid waste generation and bio gas facilities (CPCB, 2016 and MNRE, 2017) State

Bio Energy Potential (in MW)

Solid Waste Generation (tonnes/day)

Bio Gas Facilities

\begin{tabular}{|c|c|c|c|c|c|c|c|c|c|c|}
\hline & $\begin{array}{c}\text { Bio-mass } \\
\text { power }\end{array}$ & $\begin{array}{c}\text { Bagasse } \\
\text { cogeneration }\end{array}$ & $\begin{array}{c}\text { Waste to } \\
\text { energy }\end{array}$ & Generated & Collected & Treated & $\begin{array}{l}\text { Land } \\
\text { Filled }\end{array}$ & $\begin{array}{l}\text { Set } \\
\text { Up }\end{array}$ & $\begin{array}{c}\text { Operati- } \\
\text { onal }\end{array}$ & $\begin{array}{l}\text { Installed } \\
\text { / planned }\end{array}$ \\
\hline Andhra Pradesh & 578 & 300 & 123 & 6470 & 6396 & 1623.5 & 233 & 7 & 7 & 1 \\
\hline Arunachal Pradesh & 8 & - & - & 16.2 & 11.76 & - & - & - & - & - \\
\hline Assam & 212 & - & 8 & 8110 & 7200 & 200 & - & - & - & - \\
\hline Bihar & 619 & 300 & 73 & - & - & - & - & - & - & - \\
\hline Chhattisgarh & 236 & - & 24 & 6000 & 4200 & 20 & - & - & - & - \\
\hline Goa & 26 & - & - & 226.8 & 218.8 & - & 26.05 & - & - & - \\
\hline Gujarat & 1221 & 350 & 112 & - & 10527 & 757 & 9770 & 1 & 1 & - \\
\hline Haryana & 1333 & 350 & 24 & 4514 & 3159.8 & 188 & 2371.8 & - & - & - \\
\hline Himachal Pradesh & 142 & - & 2 & 342.35 & - & - & - & - & - & - \\
\hline Jammu \& Kashmir & 43 & - & - & - & - & - & - & - & - & - \\
\hline Jharkhand & 90 & - & 10 & - & - & - & - & - & - & - \\
\hline Karnataka & 1131 & 450 & & 11186 & 9706 & 3475 & 5170 & 13 & 13 & 3 \\
\hline Kerala & 1044 & - & 36 & - & - & - & - & - & - & - \\
\hline Madhya Pradesh & 1364 & - & 78 & 6773 & 5480 & 1141 & 4339 & 1 & 1 & - \\
\hline Maharashtra & 1887 & 1250 & 287 & 23449.66 & 23079.57 & 7543.1 & 15536.47 & 38 & 34 & 6 \\
\hline Manipur & 13 & - & 2 & - & - & - & - & - & - & - \\
\hline Meghalaya & 11 & - & 2 & 187 & 156 & 36 & 120 & - & - & - \\
\hline Mizoram & 1 & - & 2 & 159.88 & 159.88 & - & - & - & - & - \\
\hline Nagaland & 10 & - & - & 337 & 255 & 28 & 7 & - & - & - \\
\hline Orissa & 246 & - & 22 & 18.55 & 14.28 & 30 & - & - & - & - \\
\hline Punjab & 3172 & 300 & 45 & 4544.35 & 4520.35 & 39.175 & 3278.6 & - & - & - \\
\hline Rajasthan & 1039 & - & 62 & - & - & - & - & - & - & - \\
\hline Sikkim & 2 & - & - & 76.04 & 62.1 & 11.05 & - & - & - & - \\
\hline Tamil Nadu & 1070 & 450 & 151 & 14658.5 & 14416.63 & 4776.218 & 7336.951 & 39 & 39 & 5 \\
\hline Tripura & 3 & - & 2 & 428.09 & 379.2 & 134.4 & 244.8 & - & - & - \\
\hline Uttar Pradesh & 1617 & 1250 & 176 & 15500 & 12000 & 3115 & - & - & - & - \\
\hline Uttarakhand & 24 & - & 5 & 1180 & 1180 & - & - & - & - & - \\
\hline West Bengal & 396 & - & 148 & 14000 & 12600 & 830 & 515 & - & - & - \\
\hline Andaman \& Nicobar & - & - & - & 115 & 115 & 26.45 & 88.55 & - & - & - \\
\hline Chandigarh & - & - & 6 & 450 & 450 & 61.157 & 410.8 & 2 & 1 & - \\
\hline Delhi & - & - & 131 & - & - & - & - & - & - & - \\
\hline Puducherry & - & - & 3 & 398.5 & 398.5 & 10 & 388.5 & 2 & 2 & 1 \\
\hline Others & - & - & 1022 & - & - & - & - & - & - & - \\
\hline
\end{tabular}


Table 4 shows the solid waste generation rate in tonnes/day, set-up bio-gas facilities that are operational and planned, and the table provides data regarding the total bio-energy potential in MW for the various Indian states and union territories as per the data given in reports of CPCB and MNRE.

2.3 Refuse Derived Fuel (RDF): The non-recyclable processed MSW having high calorific value can be used as RDF in boiler/ furnaces as alternate fuel or as a fuel for electricity generation. RDF is a mixture of composition having combustible materials with high concentrations than in the original mixed MSW. RDF projects in India fall under the Electricity Act of 2003 and are monitored by Environment Protection Act adhering to emission standards along with National Ambient Air Quality Standards 2009. RDF is generally used in coal fired power plants for co-combustion and in cement kilns for co-processing (CPCB, 2016).

2.4 Gasification: Two types of gasifier designs can be found in India namely: firstly the NERIFIER unit at Hanugarh, Rajasthan established by NEERI for agro-wastes, forest wastes, sawmill dust burning, and, secondly the one at Gaul Pahari campus, New Delhi is the TERI unit (Kaushal et al, 2012). Feeding rate of waste is $50-150 \mathrm{~kg} / \mathrm{h}$ with $70-80 \%$ efficiency and fuel gas produced of about $25 \%$ is recycled back and rest is used for generating power (NEERI, 2005).

2.5 Pyrolysis: It is a destructive distillation process where indirect heat when applied, volatiles get captured. Carbohydrate polymers like hemicellulose and cellulose are first degraded and then converted. It produces bio-oil which fulfils energy recovery and secondly it recovers solids left at the end of the process which fulfils the material recovery.

2.6 Challenges using incineration, pyrolysis and gasification in India: It is a destructive distillation process where indirect heat when applied, volatiles get captured. Carbohydrate polymers like hemicellulose and cellulose are first degraded and then converted. It produces bio-oil which fulfils energy recovery and secondly it recovers solids left at the end of the process which fulfils the material recovery.

- Inadequacy in waste collections, low calorific value composition of waste, high moisture composition in the feedstock, poor planning, lack of inter institutional coordination and cooperation can be considered as the reasons for failure of the closed wte incineration plants (Mohapatra, 2015).

- Segregation and pre-sorting is required to give a homogeneous product because if the quality of waste incoming is fluctuating then RDF buffers.

- Also, all incinerators whether including RDF or not demand mandatory 4-6 weeks annual shut-down for maintenance purposes (CPCB, 2016).

- Waste of high calorific value is needed as feedstock whereas if it is used for compost it will be more environmentally safe as well as cost effective.

- Specific quality of feedstock required is required in case of pyrolysis and gasification for commercial viability of the product and improved efficiency. For specific size and characteristics of waste, pre-treatment is required (CPCB, 2016).

2.7 Anaerobic digestion: Table 5 lists the plants and their methane producing capacity along with the type of waste used as raw material (Dhar et al, 2017). Apart from this, SSS-NIRE, at Wadala Kalan, District Kapurthala (Punjab) is an autonomous Institution of the Ministry which focuses on biomass energy research and its development. The centre for testing and certification of cookstoves with testing of available cookstove models as per new BIS norms has begun its operation. One natural draft cook stove model has been designed and developed at the Institute with different possible modifications using locally available materials and is in the process for approval. In addition, research projects on process development for bioethanol production from agricultural residues and biogas production and utilization of heat and power generation applications using potential alternative feedstocks continued (MNRE, 2017).

Table 5. Anaerobic digestion plants and their methane producing capacity (Dhar et al, 2017)

\begin{tabular}{|c|c|c|c|c|}
\hline Plant & $\begin{array}{c}\text { Capacity produced } \\
\text { of } \mathrm{CH}_{4}\left(\mathrm{~m}^{3} / \text { day }\right)\end{array}$ & Type of waste & $\begin{array}{c}\text { Commissioned } \\
\text { year }\end{array}$ & Comments \\
\hline $\begin{array}{l}\text { Satara, } \\
\text { Maharashtra }\end{array}$ & 25,000 & Sugar & - & $\begin{array}{l}\text { Installed under the Indo-German Partnership for } \\
\text { Development and produces biogas from } 600 \mathrm{~m}^{3}\end{array}$ \\
\hline $\begin{array}{l}\text { Talwade, Nashik, } \\
\text { Maharashtra }\end{array}$ & 500 & Kitchen wastes & 2011 & $\begin{array}{l}\text { NISARGUNA technology aided by MNRE and } \\
\text { developed in } 2004 \text { by BARC is used that produces } 98 \% \\
\text { pure biogas }\end{array}$ \\
\hline $\begin{array}{l}\text { Sundarpur, Anand, } \\
\text { Gujarat }\end{array}$ & 5,000 & $\begin{array}{l}\text { Agricultural wastes like potato } \\
\text { peels, sugarcane waste, animal } \\
\text { dung, potato peels }\end{array}$ & 2015 & - \\
\hline Panjab & 600 & $\begin{array}{l}\text { Kitchen waste, poultry waste, } \\
\text { cattle dung }\end{array}$ & 2011 & $\begin{array}{l}\text { Multistage Up-flow Anaerobic Sludge Blanket Reactor } \\
\text { Technology is used that produces } 98 \% \text { biogas }\end{array}$ \\
\hline $\begin{array}{l}\text { Nigarguna, } \\
\text { Mangalore }\end{array}$ & $100-160$ & $\begin{array}{l}\text { Kitchen waste originating from } \\
\text { hotels, other vegetable wastes }\end{array}$ & - & Bio-waste of $2 \mathrm{MT}$ is processed daily \\
\hline $\begin{array}{l}\text { Palayam, } \\
\text { Thiruvananthpuram }\end{array}$ & $\begin{array}{l}30 \mathrm{~kW} / \text { day of } \\
\text { electricity }\end{array}$ & $\begin{array}{l}\text { Vegetable and fish leftovers } \\
\text { from market }\end{array}$ & - & $\begin{array}{l}\text { Raw materials from } 1,500 \text { household wastes } \\
\text { approximately is used }\end{array}$ \\
\hline
\end{tabular}


2.8 Landfill with gas recovery: In India total number of dumping sites is 2120 out of which the solid waste dumping sites converted into sanitary landfill are present in Chandigarh, Madhya Pradesh, Meghalaya, Sikkim, Tamil Nadu in India. There are total 21 such sites in actual practice in India and about 40 sites are reclaimed or capped for this practice (Beyene $e t$ al, 2018).

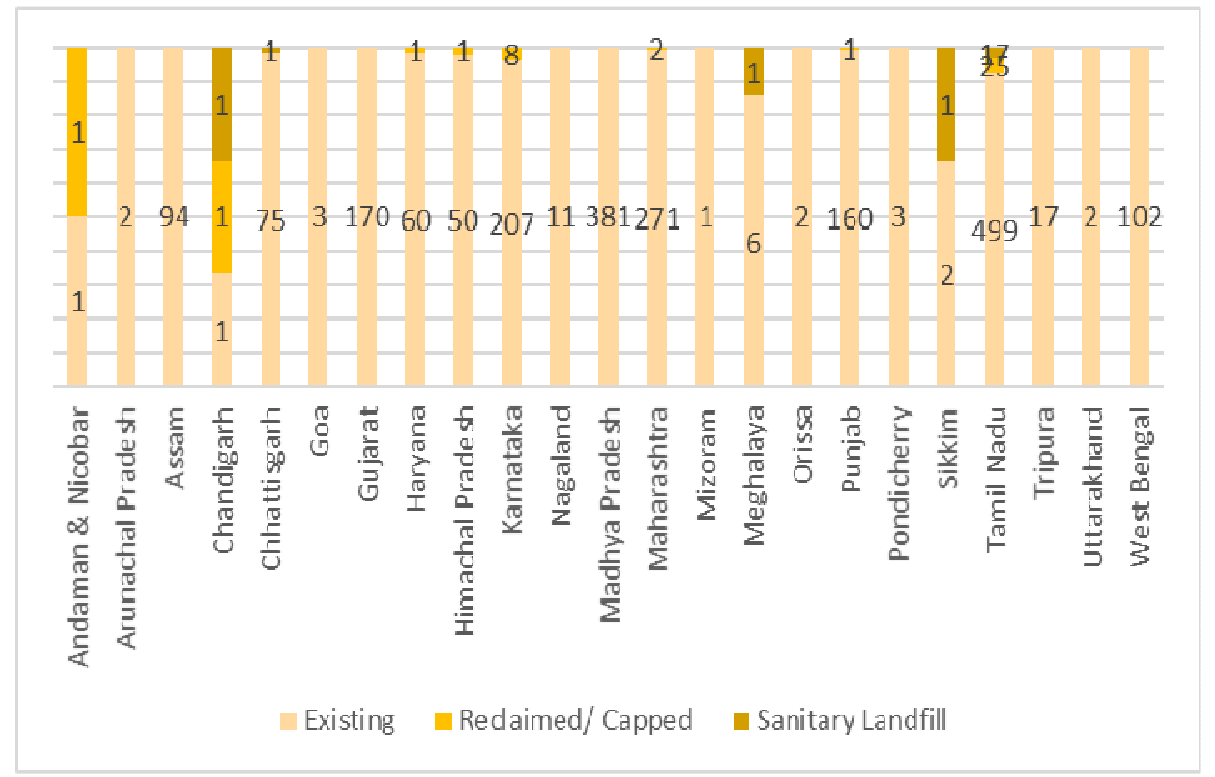

Figure 1. Current landfill status of existing, reclaimed/ capped and sanitary landfill in India (Beyene et al, 2018)

\section{Recent studies related to solid waste management in India}

Some of the recent research studies related to solid waste management in the global scenario as well as characteristics, quantity, viability and forecasting in India have been listed in brief in the following table 6. The table also specifies the area of study of each research work taken, the critical observations found and thereafter a summarized conclusion is then stated pertaining to the study conducted in the works.

Table 6. Recent research works related to solid waste management in India

\begin{tabular}{|c|c|c|c|}
\hline Study area & Description of the study & Critical observation & Comments \\
\hline $\begin{array}{l}\text { Waste to energy } \\
\text { options -global } \\
\text { scenario (Kumar et al, } \\
\text { 2017) }\end{array}$ & $\begin{array}{l}\text { Studied the current scenario of } \\
\text { waste to energy technologies } \\
\text { globally for developed and } \\
\text { developing countries based on } \\
\text { case studies in some countries. }\end{array}$ & $\begin{array}{l}\text { 1. Stated that unsanitary landfilling was the most } \\
\text { commonly adopted practice for waste disposal in } \\
\text { developing countries. } \\
\text { 2.Potential of waste technologies has been realized } \\
\text { in developed countries and is effectively practiced. }\end{array}$ & $\begin{array}{l}\text { Framework provided for evaluating } \\
\text { waste to energy practices may help } \\
\text { meet energy demand as well as } \\
\text { effectively manage waste disposal. }\end{array}$ \\
\hline $\begin{array}{l}\text { Characteristics and } \\
\text { quantity of municipal } \\
\text { solid waste in India } \\
\text { (Kaushal } \text { et al, 2012) }\end{array}$ & $\begin{array}{l}\text { Analyzed the changes in the } \\
\text { trend in characteristics and } \\
\text { quantities of municipal solid } \\
\text { waste in major urban cities in } \\
\text { India over the past four } \\
\text { decades. }\end{array}$ & $\begin{array}{l}\text { Highlighted the change in need of technologies } \\
\text { with respect to changed pattern. }\end{array}$ & $\begin{array}{l}\text { Quantity estimation may help better } \\
\text { forecasting over efficient planning for } \\
\text { successful management. }\end{array}$ \\
\hline $\begin{array}{l}\text { Skeptic views in } \\
\text { Indian scenario on } \\
\text { viability of waste to } \\
\text { energy (Mohapatra, } \\
\text { 2015) }\end{array}$ & $\begin{array}{l}\text { Discussed issues related to } \\
\text { waste to energy plants in India }\end{array}$ & $\begin{array}{l}\text { Realized need to adhere the construction of waste } \\
\text { to energy plants considering stringent emission } \\
\text { standards furans and dioxins during incinerating. }\end{array}$ & $\begin{array}{l}\text { Recognized hurdles and failure causes } \\
\text { of running of waste to energy plants } \\
\text { in India. }\end{array}$ \\
\hline $\begin{array}{l}\text { Review scenario of } \\
\text { waste to energy in } \\
\text { India (Dhar et al, } \\
\text { 2017) }\end{array}$ & $\begin{array}{l}\text { Focused on reviewing recent } \\
\text { scenarios of organic waste } \\
\text { potentials, technol-ogies and } \\
\text { the variety of challenges } \\
\text { associated with them in India. }\end{array}$ & $\begin{array}{l}\text { 1.Technical feasibility was proven at few places in } \\
\text { India. } \\
\text { 2.Challenges include- high capital cost, source } \\
\text { segregation, operating and maintenance cost, } \\
\text { skilled manpower and variations in climatic } \\
\text { conditions. } \\
\text { 3. Operating biogas plants were not shut due to } \\
\text { failure of technology but due to unworthy cost- } \\
\text { benefit analysis and non-customization of plants } \\
\text { considering local situations. }\end{array}$ & $\begin{array}{l}\text { 1.Challenges can be overcome by } \\
\text { segregation at source, appropriate } \\
\text { technology adoption. } \\
\text { 2.Focus should be more on field trial } \\
\text { of waste to energy technologies. } \\
\text { 3.Stakeholder's synchronization } \\
\text { should be motivated. } \\
\text { 4.Public awareness to encourage } \\
\text { citizens' participation. }\end{array}$ \\
\hline
\end{tabular}




\section{Conclusions}

The facilities for waste to energy that have been established in India are not sufficient to cope with the waste generation statistics. New research works like NISARGRUNA technology, bioethanol production from agricultural residues and potential alternative feedstocks need to be promoted and implemented to evolve methods that are required keeping in mind the current Indian waste scenario. For faster rate of decomposition organic waste size of particle should be less, high density instead of low density (such as plastics, paper, cardboard).

In case of anaerobic digestion suitability increases with high moisture content. In India, organic material in waste is high (40$60 \%$ ), inert content is also high (30-50\%) along with high moisture content (40-60\%) and low calorific value (of about 800-1100 $\mathrm{kcal} / \mathrm{kg}$ ). The main consideration of any fuel economy is its heating value so this should also the attention should be paid to improving the calorific value in the existing plant setups.

\section{Nomenclature}

$\begin{array}{ll}\text { CPCB } & \text { Central Pollution Control Board } \\ \text { CPHEEO } & \text { Central Public Health and Environmental Engineering Organisation } \\ \text { IEA } & \text { International Energy Agency } \\ \text { MNRE } & \text { Ministry of New and Renewable Energy } \\ \text { MSW } & \text { Municipal solid waste } \\ \text { NEERI } & \text { National Environmental Engineering Research Institute } \\ \text { SSS-NIRE } & \text { Sardar Swaran Singh National Institute of Renewable Energy } \\ \text { WTE } & \text { Waste to energy }\end{array}$

\section{Acknowledgement}

This work was supported to me in my Masters Research program under the guidance of Dr. Jeeoot Singh of Department of Mechanical Engineering at Madan Mohan Malaviya University of Technology Gorakhpur. I would like to thank him for his extraordinary support and collaboration in completion of my work.

\section{References}

ASME., 2008. Waste-to-energy: a renewable energy source from municipal solid waste. American Society of Mechanical Engineers. White paper submitted to Congress, New York, 2008.

Beyene H.D., Werkneh A.A. and Ambaye T.G. 2018. Current updates on waste to energy (WtE) technologies: a review. Renewable Energy Focus, Vol. 24, pp 1-11. https://doi.org/10.1016/j.ref.2017.11.001

CPCB., 2016. Consolidated annual review report on implementation of solid wastes management rules, 2016- annual review report 2015-16. Reported by Government of India Ministry of Environment, Forests and Climate Change along with Central Pollution Control Board India.

CPHEEO., 2014. Municipal solid waste management manual. Reported by Central Public Health and Environmental Engineering Organisation issued by Ministry of Urban Development, India. May 2014.

Dhar H., Kumar S.and Kumar R. 2017. A review on organic waste to energy systems in India. Bioresource Technology, Vol 245, pp 1229-1237. http://dx.doi.org/10.1016/j.biortech.2017.08.159

Kaushal R.K. and Chabukdhara M. 2012. Municipal solid waste management in India-current state and future challenges: a review. International Journal of Engineering Science and Technology, Vol. 4, pp 1473-1489. ISSN : 0975-5462.

Kaza S., Yao L., Tata P.B. and Woerden F.V. 2018. What a waste: a global snapshot of solid waste management to 2050. Urban Development Series (Washington, DC: World Bank). doi:10.1596/978-1-4648 -1329-0.

Kumar A. and Samadder S.R. 2017. A review on technological options of waste to energy for effective management of municipal solid waste. Waste Management, Vol. 69, pp 407-422. https://doi.org/10.1016/j.wasman.2017.08.046

MNRE., 2017. Ministry of New and Renewable Energy Annual Report 2016-17. Ministry of New and Renewable Energy, India.

Mohapatra. 2015. National Conference on Waste-to-Energy in India organised by Toxics Link, 2015.

NEERI., 2005. Waste generation and composition in 59 cities- annual review report 2004-05. Surveyed by National Environmental Engineering Research Institute issued by Central Pollution Control Board, India.

\section{Biographical notes}

Saumya Singh received M. Tech. from Madan Mohan Malaviya University of Technology, Gorakhpur, India in 2019 and is currently a research scholar in the Department of Mechanical Engineering, Indian Institute of Technology, Dhanbad, India. 
Dr. Jeeoot Singh is a Professor in the Department of Mechanical Engineering, Madan Mohan Malaviya University of Technology, Gorakhpur, India. He completed his M. Tech in 2001 from Indian Institute of Technology, Delhi and his PhD. in 2012 from Motilal Nehru National Institute of Technology, Allahabad .He has more than 16 years of experience in teaching and research. He has published more than fifty papers including referred international journals and conference proceedings. He has also worked on few projects sponsored by government of Bihar, India. 